\title{
PROFESOR HANNA KONOPKA
}

(1949-2015)

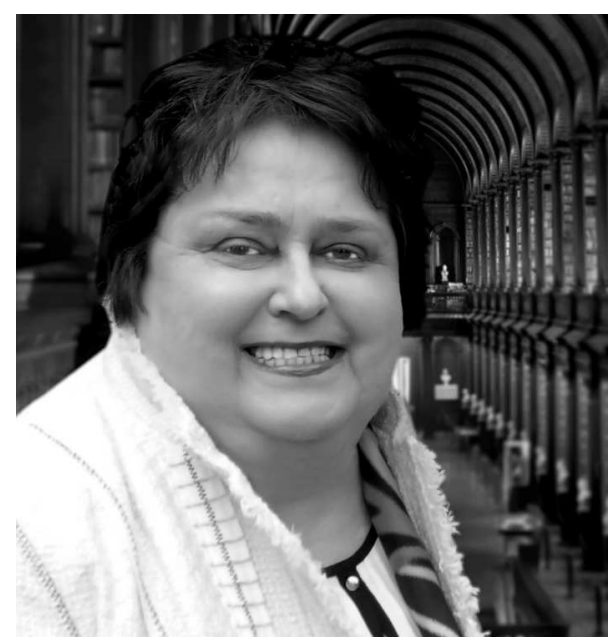

W niedzielny poranek, 18 października 2015 r., zmarła prof. zw. dr hab. Hanna Konopka. Poważne problemy zdrowotne Pani Profesor rozpoczęły się przed kilku laty. Przez ten czas zdążyliśmy się przyzwyczaić, że Profesor Hanna Konopka, intensywnie uczestnicząc w życiu naukowym, systematycznie, z właściwym sobie optymizmem, pokonuje wszystkie przeciwności. Przyzwyczailiśmy się, że podejmując kolejne inicjatywy, wspierając swoich studentów i doktorantów w ich pracach naukowych, Pani Profesor oddala się od swoich problemów zdrowotnych. Uwierzyliśmy, że ta niesamowita aktywność dodaje Pani Profesor Hannie Konopce sił. Pewnie jest w tym sporo prawdy, ale myślę, że równie dobrze moglibyśmy spojrzeć na to inaczej. Moim zdaniem, Pani Profesor była osobą wyjątkową. Przede wszystkim, swoją chorobę przyjęła z wielkim spokojem. Nauczyła się z nią żyć i normalnie funkcjonować. I to jak funkcjonować... Wciąż wyjeżdżała na konferencje naukowe, snuła i realizowała poważne plany, pełniła odpowiedzialne funkcje. Ponadto, miała - wydawałoby się - niespożyte siły. Na zawsze zapamiętam obraz Pani Profesor, sprawdzającej, podczas kolejnego pobytu w szpitalu, pracę doktorską jednego z kolegów. Zastanowiłem się wówczas, ilu osobom chciałoby się w takiej sytuacji czytać i poprawiać czyjąś pracę? Byliśmy jej za to wdzięczni. Sprawy ważne dla nas, Jej uczniów, były ważne także dla Pani Profesor. 
Wielokrotnie byłem świadkiem, ale jako uczeń Pani Profesor także i odbiorcą, bardzo krytycznych uwag w odniesieniu do prób pisarskich podejmowanych przez początkujących badaczy. Uwag bezceremonialnych, które wydawałoby się mogły zniechęcić. Mimo to, seminaria licencjackie, magisterskie oraz seminarium doktorskie prowadzone przez Panią Profesor Hannę Konopkę cieszyły się zawsze ogromnym zainteresowaniem. Wszak Pani Profesor wypromowała około trzystu magistrów historii, pięciu doktorów, zaś liczby licencjatów nie jestem w stanie zliczyć. Moim zdaniem, był to swoisty fenomen. Myślę, że o tej popularności wśród studentów decydowała osobowość Pani Profesor. Bowiem Profesor Hanna Konopka nie ograniczała się jedynie do uwag i krytyki. Znakomicie potrafiła motywować swoich uczniów do pracy, wspierać w trudnościach, tych naukowych i życiowych. Była dla nas znakomitym MISTRZEM i NAUCZYCIELEM.

Zanim Hanna Konopka w 1974 r. podjęła pracę naukową na Filii Uniwersytetu Warszawskiego w Białymstoku, uczyła historii w szkole podstawowej $\mathrm{w}$ pobliżu Zawiercia, następnie kolejno $\mathrm{w}$ białostockich szkołach podstawowych nr 29, 6 i 2.

Kariera naukowa Pani Profesor Hanny Konopki, nawet według obecnie obowiązujących standardów, była wzorcowa. Poszczególne stopnie naukowe uzyskiwała na różnych uczelniach w kraju. Magisterium - na Uniwersytecie Śląskim, doktorat - na Wydziale Historycznym Uniwersytetu Warszawskiego (1984), habilitację - na Wydziale Humanistycznym Katolickiego Uniwersytetu Lubelskiego (1996). Natomiast w lutym 2015 r. Hanna Konopka otrzymała tytuł naukowy profesora nauk humanistycznych.

W dorobku naukowym Profesor Hanny Konopki znajduje się około 140 publikacji. Ponadto kilkadziesiąt recenzji wydawniczych, recenzji egzaminów gimnazjalnych i maturalnych, opracowań i ekspertyz. Profesor Hanna Konopka specjalizowała się w badaniach problemów historii Kościoła w Polsce Ludowej. Szczególnie ważną i nowatorską publikacją Jej autorstwa była monografia zatytułowana Religia w szkołach Polski Ludowej. Sprawa nauczania religii w polityce państwa 1944-1961 (Białystok 1995, Białystok 1997). Oprócz licznych artykułów poświęconych tej tematyce, publikowanych w wielu krajowych czasopismach naukowych, wydała także drukiem zbiór dokumentów, zatytułowany 17 lat nauczania religii w Polsce Ludowej. Wybór dokumentów (Białystok 1998). Kolejnym obszarem zainteresowań naukowych Profesor Hanny Konopki były problemy z zakresu dydaktyki historii i wiedzy o społeczeństwie. Pani Profesor była więc autorką m.in. przewodników metodycznych i programów szkolnych dopuszczonych do użytku przez MEN (Wiedza o społeczeństwie. Program nauczania. III etap 
edukacyjny. Gimnazjum klasy I-III, Warszawa 1999; Wiedza o społeczeństwie. Wychowanie obywatelskie $w$ gimnazjum. Przewodnik metodyczny $i$ program nauczania, Warszawa 1999; Wiedza o społeczeństwie. Wychowanie do aktywnego udziału w życiu gospodarczym. Przewodnik metodyczny i program nauczania, Warszawa 2000). Ponadto, Profesor Hanna Konopka była też autorką podręczników dla gimnazjów (Wiedza o społeczeństwie. Wychowanie obywatelskie. Podręcznik dla gimnazjów, Warszawa 1999; Wiedza o społeczeństwie. Wychowanie do aktywnego udziału w życiu gospodarczym. Podręcznik dla gimnazjów, Warszawa 2000; Edukacja europejska. Ścieżka edukacyjna dla gimnazjum, Warszawa 2000). W ostatnich latach życia Profesor Hanna Konopka podjęła badania dotyczące problemów bezpieczeństwa narodowego. Efektem tych zainteresowań była monografia pt. Bezpieczeństwo edukacji, edukacja dla bezpieczeństwa (Białystok 2013).

Poza pracą naukową i dydaktyczną Pani Profesor podejmowała liczne działania organizacyjne. Przedstawienie tej aktywności w tak krótkim tekście jest niemożliwe. Należy jednak wymienić, że od 1999 r. kierowała Zakładem Dydaktyki Historii i Wiedzy o Społeczeństwie, zaś w latach 2000-2003 była dyrektorem Instytutu Historii Uniwersytetu w Białymstoku. Ponadto w latach 2003-2006 i 2007-2010 Profesor Hanna Konopka została wybrana w skład Komitetu Nauk Historycznych Polskiej Akademii Nauk. Natomiast w latach 1995-2009 pełniła z upoważnienia UwB funkcję przewodniczącej Zarządu, a następnie Rady Fundacji im. Ludwika Zamenhofa w Białymstoku. W 2009 r. Pani Profesor zrezygnowała z pracy na Uniwersytecie w Białymstoku. Jednak wciąż była aktywna naukowo, bowiem pracowała w Wyższej Szkole Administracji Publicznej w Białymstoku. W lutym 2014 r. na krótko objęła stanowisko rektora tej uczelni.

Na zakończenie pozwolę sobie na włączenie wątku osobistego. Miałem ogromne szczęście być studentem, podwładnym i współpracownikiem Pani Profesor. Z dumą mogę powiedzieć, że Pani Profesor Hanna Konopka była moją Mistrzynią i Wielkim Przyjacielem. Przyjaźniliśmy się też rodzinami. W każdej z tych ról Pani Profesor była niepowtarzalna. Jako nauczyciel akademicki i przełożona potrafiła zainteresować problemem, mądrze pokierować, doradzić. To Pani Profesor, promotorce mojego doktoratu, zawdzięczam podjęcie badań poświęconych strukturze i funkcjonowaniu KW PZPR w Białymstoku w latach 1948-1956. Po wielu dyskusjach problem, który początkowo wydawał mi się mało interesujący w pełni mnie pochłonął. Zawsze byłem i będę wdzięczny Pani Profesor za wsparcie i zaufanie, jakim mnie obdarzyła. Pani Profesor była też znakomitym Przyjacielem. Wykazywała troskę nie tylko o moje sprawy zawodowe, ale też wspierała w trudnościach 
życia codziennego. Jej ciepłe, spokojne słowa dodawały siły, wprowadzały nadzieję. Bardzo brakuje i będzie mi brakować długich dyskusji, mądrych uwag i szczerego uśmiechu na twarzy Pani Profesor.

Artur Pasko, dr hab., pracuje w Instytucie Historii i Nauk Politycznych Uniwersytetu w Białymstoku.

e-mail: arturpasko@wp.pl 